\title{
FLIPPING THE CLASSROOM: HOW REVERSING TEACHING-LEARNING PROCESS CAN IMPROVE LEARNER'S COMPREHENSION IN LEARNING FOREIGN LANGUAGE
}

\author{
Wishnoebroto \\ Language Center, BINUS University \\ Jln. Kemanggisan Ilir III No.45, Kemanggisan - Palmerah, Jakarta Barat 11480 \\ Wishnoebroto@binus.edu
}

\begin{abstract}
Flipping a classroom is not only recording classroom lesson into a video and bringing homework into the classroom. It is a whole new method with a lot better result compared to the traditional method. In western countries such as the US, flipping a classroom is already becoming a new method adopted by many different schools and universities. This paper tries to explore the possibility of flipping a classroom for learning foreign language at BINUS University by comparing it with the recent practices and findings in the western countries. After the analysis it can be concluded that this method can be applied at BINUS University but on several conditions such as the improvement of infrastructures, and the teacher's awareness and understanding to optimize their understanding about flipped learning.
\end{abstract}

Keywords: flipping classroom, ICT, content management system, blended learning

\begin{abstract}
ABSTRAK
Flipping classroom tidak hanya sekadar membalik urutan proses belajar mengajar, merekam kuliah dalam bentuk video dll. Ini adalah sebuah metode baru yang hasilnya dapat jauh lebih baik jika dibandingkan dengan metode tradisional. Meskipun terlihat menjanjikan, ada banyak faktor yang harus dipertimbangkan sebelum melakukan flipping terutama jika itu dilakukan dalam kelas pembelajaran bahasa. Paper ini mencoba untuk menggali beberapa kemungkinan jika flipping dilakukan di BINUS University dengan cara membandingkan antara kelas yang dilakukan sekarang dengan yang sudah dilakukan di negara barat.
\end{abstract}

Kata kunci: flipping classroom, ICT, content management system, blended learning 


\section{INTRODUCTION}

Traditionally, teachers explain and students listen. Like in Indonesia, textbook is used as the materials learned in the classroom and also as the major references. In the classroom, learners or students are expected to pay attention, listening to the teacher's explanation, and taking notes using that information to do the homework or for the next subject.

The problem with this process is that learners sometimes-or most of the times-cannot get all the information they need to do the homework. If for some reasons, a student's attention is distracted, then he or she will be lost valuable information. Ironically, if the students cannot write fast enough, he or she cannot rewind and replay the information. On the other side, teachers, as the knowledge provider, also cannot cover the materials clearly and comprehensively because the time provided is too short. Not mentioning problems such as technical errors, disturbances and many other kinds of distractions. Most likely, teachers will ask their students to cover the unexplained materials by studying the materials in the textbook at home. That explains why many students took extra courses to improve their understandings about the course matter.

Thanks to the technology nowadays, students can record either video or audio of what has been explained in the classroom. The technology makes learning more personal and easy to manage. However, not everybody understands how to make use the technology to improve and to make the learning process more exciting. One way to do it is to reverse or flip the learning process by using information and multimedia technology.

\section{Literature Review: Flipping the Classroom and Blended learning}

Flipping the classroom is a way where students learn in the opposite way compared to the traditional learning method. Rutherfoord et al (2000) mentioned that it all began in the early nineties when Prof Eric Mazur from Harvard University inverted his classroom to accommodate students with different learning styles. He thinks that students will learn better if they are given more time to interact outside the classroom. Therefore, he reverses the course by recording himself in front of camera teaching the students so that they can follow or repeat the course anywhere, anytime.

Additionally, he also said that the basic idea of a flipped classroom is creating videos to take the place of face-to-face instruction. In the video, teacher explains and interact the students. It is not just an online video where students are staring and listen about it. Therefore, the next requirement is to provide activities for students to work with peers and faculty out of the classroom to assist in learning. This means, students and faculty can engage and interact one another freely outside the classroom. With more time for interacting, students and teachers can encourage students to become independent and to take responsibility of their own learning. (Rutherfoord et al., 2000)

The basic notion that supports the flipped classroom is stated by Bransford, Brown, and Cocking (2000). They reported the key findings on how people learn, including the logic behind the flipped classroom method. Bransford, Brown, and Cocking (2000:363) stated: "To develop competence in an area of inquiry, students must: a) have a deep foundation of factual knowledge, $b$ ) understand facts and ideas in the context of a conceptual framework, and c) organize knowledge in ways that facilitate retrieval and application.” Therefore, it can be concluded that the flipped classroom can only be applied where students have understood at least the basic principle of the knowledge or materials being discussed. Teachers who are flipping the classroom should conduct a thorough and comprehensive supervision to monitor the process. Still according to them, the best assessment for students in a loosely structured classroom like the flipped classroom is the one that can tap students understanding rather than reciting memorized information. That means the repeated formative test can be conducted to get a picture of the learners so teachers can visualize and conduct actions to improve the learning quality of the group (Bransford et al., 2000). 
In connection between education and technology, flipping a classroom can only be conducted when both students and teachers understand about how to use the technology. It is important to know how well the people involved in this kind of classroom understand each of their roles. In classroom context, students and teachers both use technology to dig information, but the question is how they are going to use it, whether the idea of learning is still in their mind when they surf to get information. This is where Blended Learning was introduced. Blended learning is an idea when the teaching learning process is combined between the face-to-face and online. The idea comes from the industry when people think that learning can be conducted more efficientlythrough online since it can reduce the meeting time and also learning can be done collaboratively from anywhere (Sharma, 2010). Sharma (2010) also mentioned that there are three different kinds of blended learning, which are suitable to be applied in a classroom context: Combination between face-to-face and online teaching; this is considered the most traditional blended learning since the idea is to ask learners to sit in the classroom while at the same time, using online resources and platforms such as Moodle and Blackboard to improve the learning management system. Combination between technologies; this model is mostly used in distance learning where the frequency of meeting between learners is fully accommodated online; combination of methodologies; it was mentioned about how the ideas and methods of learning are combined and integrated into one. The idea of constructivism where learners are expected to create their own concept of knowledge is combined with knowledge transmission, which is fully supported by information technology (Sharma, 2010). Sharma also adds that with the vast Internet coverage in the world, it is possible that learning will be conducted simultaneously and remotely without border. The Massive Open Online Course(s) or MOOCs is the example of this growing trend.

From these three different approaches, it is clearly seen that there is a big possibility for teachers to flip a class and make learning to be different. However, the question is how to apply this approach for language class. What skills can be covered, what is the procedure, and how to maintain quality as well as monitoring the result of the course taught to the learners. This paper will explore possibilities of flipping classroom for language classes.

The following table illustrates the significant difference before and after the classroom is flipped.

Table 1 Differences before and after the classroom flipped

\begin{tabular}{|c|c|c|}
\hline & $\begin{array}{c}\text { OLD } \\
\text { (Before the Flip) }\end{array}$ & $\begin{array}{c}\text { NEW } \\
\text { (After the Flip) }\end{array}$ \\
\hline Before Class & $\begin{array}{l}\text { Students assigned something to read } \\
\text { Instructor prepares lecture. }\end{array}$ & $\begin{array}{l}\text { Students guided through learning module that asks } \\
\text { and collects questions. } \\
\text { Instructor prepares learning opportunities. }\end{array}$ \\
\hline \multirow[t]{2}{*}{ Beginning of Class } & $\begin{array}{l}\text { Students have limited information } \\
\text { about what to expect. }\end{array}$ & $\begin{array}{l}\text { Students have specific questions in mind to guide } \\
\text { their learning }\end{array}$ \\
\hline & $\begin{array}{l}\text { Instructor makes general assumption } \\
\text { about what is helpful. }\end{array}$ & $\begin{array}{l}\text { Instructor can anticipate where students need the } \\
\text { most help. }\end{array}$ \\
\hline \multirow[t]{2}{*}{ During Class } & Students try to follow along. & $\begin{array}{l}\text { Students practice performing the skills they are } \\
\text { expected to learn. }\end{array}$ \\
\hline & $\begin{array}{l}\text { Instructor tries to get through all the } \\
\text { material. }\end{array}$ & $\begin{array}{l}\text { Instructor guides the process with feedback and } \\
\text { mini-lectures. }\end{array}$ \\
\hline \multirow[t]{2}{*}{ After Class } & $\begin{array}{l}\text { Students attempt the homework, } \\
\text { usually with delayed feedback. }\end{array}$ & $\begin{array}{l}\text { Students continue applying their knowledge skills } \\
\text { after clarifications and feedback. }\end{array}$ \\
\hline & Instructor grades past work. & $\begin{array}{l}\text { Instructor posts any additional explanations and } \\
\text { resources as necessary and grades higher quality } \\
\text { work. }\end{array}$ \\
\hline Office Hours & $\begin{array}{l}\text { Students want confirmation about } \\
\text { what to study. } \\
\text { Instructor often repeats what was in } \\
\text { lecture. }\end{array}$ & $\begin{array}{l}\text { Students are equipped to seek help where they know } \\
\text { they need it. } \\
\text { Instructor continues guiding students toward deeper } \\
\text { understanding. }\end{array}$ \\
\hline
\end{tabular}

(Source: Kopp, n.d.) 


\section{METHOD}

This paper only tries to compare and see the possibility of applying the method into practice of recent condition at BINUS University. This qualitative research tries to refer what had been done previously based on finding $\mathrm{s}$ published in journals and many research papers with the recent conditions at BINUS University Jakarta. These comparisons then analyzed and reported systematically.

Various researches were conducted concerning on how to integrate blended learning in many different subjects. Šafranj (2013), for example, has proven that blended learning is proven to be effective in improving all language skills for ESP (English for specific purposes) students. She said: "A blended approach in learning English for Specific Purposes in higher education can appreciably enhance students' results and experience by providing a more student- centered learning environment."(Šafranj, 2013)

In other occasion, Maulan and Ibrahim (2012) conducted research of teaching and learning of English for academic purposes at Universiti Teknologi MARA Melaka. The research involved a total of 963 students and 23 lecturers and it was found out that the students perceived blended learning positively where they can engage each other through examination and discussion. However, they mentioned the major problem in applying blended learning approach in their institution was on the lack of technical support and he inefficiency of the LMS system. On the other hand, they stated that there was significant difference between students who involved in blended learning with students who did not (Maulan \& Ibrahim, 2012).

Another research by Ellis and Goodyear (2006) supports the notion that blended learning can be successful only when learners has mastered or at least deeply understood about the course subject. The research was observing second year students who were given two different approaches: learning through discussion using face-to-face interactions and discussion through online. From the result it was revealed that there was a significant difference between students who conducted discussion through face-to-face and online. The result shows that there is a correlation between students who understand about the basic conception with the one who did not. The grades shows that students who has deep understanding is getting better grades than the one who only has surface understanding. However, in the face-to-face classroom there is no strong association between those who have deep understanding with the grades (Ellis \& Goodyear, 2006). That means the face-to-face interactions still have major influence in making people understand about certain subjects. Although technology nowadays enables people to interact simultaneously, it seems that technology cannot replace the personal human interaction between the members of the discussion groups.

The first two research findings were so contrastive that it brings out the big question. What makes the result of the researches so different? Is it merely because of the technical error? Different platform? Or is it because of different habit of the learners? Does cultural background play important part in determining the result? These questions were partly answered in the third research. Ellis and Goodyear explicitly stated that the major problems in learning language through blended learning lie on the quality of interaction between the members of the groups.

Therefore, this paper is using the comparative methodology approach. It tries to compare between the existing blended learning and flipped classes proposed in this paper. The scope, however, is quite broad and general since it tries to capture the whole phenomenon and consider all possibilities, and options so the result is quite comprehensive. The comparative method is popularly proposed by Lijphart (1971) who said that comparative method is regarded as a method to "discover empirical relationships among variables, not a method of measurement." He also adds that the comparative method is a more likely a broad and general method, not a narrow, specialized technique (Lijphart, 1971). 


\section{RESULTS AND DISCUSSION}

\section{Applying the principle of flipping the classroom in BINUS University setting}

After looking at previous research, now it is clear that thereare some things need to be seriously considered before one applies blended learning, especially flipping the classroom. Therefore, this paper is going to cover the most common features and problems.

\section{Technical requirements before flipping the classroom}

Flipping a classroom requires a course management system (CMS) that can accommodate all materials including audio visual and printed materials in one place. According to Snodin (2013) a course or learning management system is a kind of application or software that is specifically designed to use in teaching and learning and it contains features such as: content organization, presentation, discussion tools, communication tools, assessments tools, grade book and other class management features (Snodin, 2013).

BINUS University has developed its own course or learning management system called BINUSMAYA, which covers all features as described above. The CMS can provide information such as students grade, assignment, presentation, discussion tools and other features. There is no specific feature or tools for language learning. Therefore, it will be the first time for BINUSMAYA if an instructor wants to flip the classroom. One important thing about blended learning for language learning is the fact that learners are supposed to understand the basic notion of learning language using computer or Computer Assisted Language Learning (CALL). CALL is basically a way where computer and information technology (ICT) is combined with language learning. In another research, CALL is said to be an ideal combination when it is used for language learning because CALL can be used to support interaction and collaboration with peers and with native speakers. Most importantly, CALL can be used to provide an experimental, learner-centered learning environment. Finally, CALL is supposed to be personal and can promote autonomous learning and motivate learners, which according to Snodin it is very contextual and still under discussion (Snodin, 2013).

Herreid and Schiller (2013) illustrate that despite the superiority of flipped classroom, there are many pitfalls that need to be considered before doing the action. The first most obvious problem is unfamiliar instruction, which makes students confused and resist because the new approach require them to work more at home. The second problem is the learning materials, which are not quite suitable with the needs of the learners. Teachers most likely search for videos in YouTube ${ }^{\circledR}$ or many other online video websites. However, it is not easy to find a good teaching - learning materials. Therefore, it needs a considerable amount of time to find and prepare the learning materials before it is embedded with the course subject (Herreid \& Schiller, 2013).

After considering Schiller's findings, this research compared the phenomenon to Indonesian students, specifically BINUS university students, who are more familiar with face-to-face interaction. This approach will surely create resistance among them. The possible solution to this problem is by integrating the course with social media. However, it is strongly suggested to use a customized social media to limit the size of the group and prevent distractions. Free social media platform such as Yammer ${ }^{\circledR}$ can be used to create a discussion group combined with the already existing BINUSMAYA to create a flipped classroom. Whereas for the materials, besides using a ready made material found in YouTube, ${ }^{\circledR}$ teachers can make their own video using free software such as Camtasia ${ }^{\circledR}$, Windows Movie Maker ${ }^{\circledR}$ or iMovie ${ }^{\circledR}$. Teachers can upload these materials in YouTube Teachers ${ }^{\circledR}$ and linked it with the Yammer ${ }^{\circledR}$ and managed it through BINUSMAYA. 
Basically, behind all of the superiority of the hardware it is strongly believed that the best way to flip a classroom is to have a strong and careful preparation. In my opinion, the most important thing to be considered in a flipped classroom is to prepare the students. I strongly suggest students to know what they expect and manage their time for discussion outside the classroom. Project based learning probably is the best learning method to be applied with this approach since it requires deep understanding, preparation, critical thinking and collaborative work.

\section{Types of courses}

There is no record that I can find about flipping the classroom for English subjects. Mostly flipped classroom is dealing with STEM (science, technology, engineering, math) subjects, which most people can find in many web-learning platform such as the Khan Academy (https://www.khanacademy.org/). For learning language, however, the stress is on how students can master foreign language where the main materials are already presented and watched at home and they have to practice it in the classroom.

By looking at the practice of flipped learning for STEM Courses, I see the opportunity of developing materials for all four- skills of languages: speaking, listening, reading and writing. For speaking the materials to be uploaded is the materials students need to practice repeatedly such as pronunciation practice. The logic behind choosing pronunciation as the flipped materials is because it is the most basic knowledge that needs to be practiced repeatedly from time to time. Through videos, learners can repeat the lesson over and over and they can practice themselves at home as many as they want. Teachers on the other hand prepare for activities in the classroom such as group work, games, or pop quiz. The assessment is using ongoing assessment where students are observed using checklist provided. It is conducted either through face-to-face meeting or through video screening. This method is the most suitable for speaking since the progress of each meeting can be measured accurately.

Although it looks promising, there is a major setback especially concerning with the level of satisfaction of the students with materials learned in the course.In the context of nursing education, Gosselin (2013) stated that flipped classroom have a positive correlation with academic result. But this result is in contrast with the satisfaction of the students. He found that students are less satisfied with the flipped classroom, which is due because students think that the new method required more work, and they did not seem to perceive the value of interactive learning approaches (Gosselin, 2013). To tackle this problem, it is strongly suggested that teacher has enough time to observe their students closely and give feedback in regular basis. With social media format like in the Yammer ${ }^{\circledR}$, teachers can focus on how to give a good coaching during the face-to-face session.

\section{Types of learners}

There is no specific age or any kinds of restrictions when a teacher wants to flip his or her class. The best result will be achieved if the learners have understood about the basic knowledge. For writing course for example, normally learners who have low comprehension in writing will find difficulties coping with the materials. However, with flipped class, learners will probably find hard to follow the class since there is no personal connection with the teachers. However, with video, teacher can do many things especially in how to connect information to the learners. Compared to traditional method where teacher stood in front and talk to students, with video teacher can demonstrate how to compose a simple writing material directly. For learners who are not visual, they can always pause, replay and listen to the course over and over. Whereas for visual learners, this kind of teaching is very effective since they can see the information being delivered.

Nowadays flipping the classroom has became one of the options for teaching at schools especially for the gifted children (Siegle, 2013). He said that flipping classroom provides freedom for children to create their own pace. They can skip once they have mastered the materials and move fast to the more advanced level. However, he said, teacher should be aware about the level of the computer 
literacy of the students. They should know the basics and dedicated their spare time to connect to the Internet to watch their teacher's classroom videos. In relation to this, students have to be selfmotivated. Otherwise, the goals will not be attained and students will be left behind. However, Siegle adds, flipping the classroom can sometimes improve student's motivation through working collaboratively (Siegle, 2013).

In Harvard University, Berrett (2012) conducted a research on students in the flipped classroom needed to be prepared and ready that the learning is not as they are expected. If they are following the flipped classroom, they are expected to ask questions regarding the materials. Now it is all depend on the professors to answer the questions. Therefore, they have to allocate extra time and effort to read and answering student's questions (Berrett, 2012).

\section{Types of assessment in the flipped classroom}

The best assessment is the one that can measure the deep understanding rather than surface understanding and to encourage measurement of factual knowledge rather than conceptual understanding. Additionally, it should also facilitates objective scoring (Bransford et al., 2000). In connection to the flipped classroom, it can be measured through ongoing assessment. In research about Blended learning in a higher education institution, Dias and Diniz (2012) stated that mostly blended learning in Higher Education Institution is relying on the Content Management System (CMS) and typically there are three weaknesses of learning through CMS. The first is the learning environment. In some case, students and teachers have different teaching - learning preference. This condition can determine the result of the course. Therefore, Dias and Diniz (2012) added that teachers should aware and flexible enough to see student's learning preference to adjust his or her assessment style but still maintain its objectivity. The second factor is teacher's s belief and the subject matter. Familiarity of the teachers with learning technology determines the engagement of the subject matter he or she delivered. Most young generations were thought to be ICT literate. However, Dias and Diniz (2012) stated that most of the problems in applying the ICT in the classroom are due to lack of familiarity about the learning system itself. Both teachers and students need time to familiarize themselves with the learning system and application used for learning.

\section{CONCLUSION}

Flipping a classroom is a way where teacher and students are engaged through online and face-to-face activity. The main difference with the traditional classroom is on how the class is conducted. In the western countries, flipping a classroom has already become a common practice in education institutions. In Indonesia, this practice is hard to be conducted mostly because of the quality of the infrastructures. An idea of flipping a classroom for language learning in BINUS University by maximizing the power of the BINUSMAYA, an LMS for BINUS University students is proposed. To add the power of the LMS, teachers must add a different, self customized social media-like platform such as Yammer ${ }^{\circledR}$. With this method, students can interact naturally through live conversation. Additionally, they can also improve their communication skills through video recording applications such as Camtasia ${ }^{\circledR}$ or iMovie ${ }^{\circledR}$ which encourage them to speak and collaborate using the target language.

From the discussion, this research proposes a set of assessment for learning language in BINUSMAYA. Firstly, there must be options where students can choose which kinds of assessment they want to have. It may sound strange, but students need to have freedom how they want to be measured. The standardized test, that most students familiar, only measure the surface understanding. Students can recite, and restated what they have memorized but it does not guarantee that they really 
understand about the subject. With ICT based learning platform, teachers can see and evaluate students' performance through different perspectives. Through Yammer ${ }^{\circledR}$ for example, teachers can see the natural flow of ideas of the students through their virtual conversations. For oral examination, teachers can ask students to share ideas through live conference or online conversation. Of course to master this, teachers have to be familiar with the technology and how it can be applied in real situation successfully.

\section{REFERENCES}

Berrett, D. (2012). How Flipping the classroom can improve the traditional lecture. The Education Digest, 79(1), 36-41.

Bransford, J., Brown, A., \& Cocking, R. (2000). How People Learn. Retrieved from http://www.csun.edu/ SB4310/How People Learn.pdf

Dias, S. B. and Diniz, J. A. (2012). Blended Learning in Higher Education: Different Needs, Different Profiles. Procedia Computer Science, 14(Dsai), 438-446. doi:10.1016/j.procs.2012.10.050

Ellis, R. and Goodyear, P. (2006). How and what university students learn through online and face-to-face discussion: Conceptions, intentions and approaches. ... Assisted Learning, 22(4), 244-256. DOI:10.1111/j.1365-2729.2006.00173.x

Gosselin, K. M. R. F. L. S. K. (2013). Flipping the Classroom to Improve Student Performance and Satisfaction. Journal of Nursing Education, Volume 52(10).

Kopp, S. (n.d.). Center for teaching + Learning The Univrsity of Texas at Austin. Retrieved September 17, 2014, from What is the Flipped Classroom?: http://ctl.utexas.edu/teaching/flipping-aclass/what

Herreid, C. F. and Schiller, N. A. (2013). Case Studies and the Flipped Classroom. Journal of College Science Teaching, 42(5), 62-66.

Lijphart, A. (1971). Comparative politics and the comparative method. The American Political Science Review, 65(3), 682-693. Retrieved from http://www.jstor.org/stable/1955513

Maulan, S. B. and Ibrahim, R. (2012). The teaching and learning of english for academic purposes in blended environment. Procedia - Social and Behavioral Sciences, 67, 561-570. doi:10.1016/j.sbspro.2012.11.361

Rutherfoord, R. H., Rutherfoord, J. K., and Drive, S. C. (2000). Flipping the Classroom - Is It For You, 19-22.

Šafranj, J. (2013). Using Information Technology in English Language Learning Procedure: Blended Learning. Procedia - Social and Behavioral Sciences, 83, 514-521. doi:10.1016/j.sbspro.2013.06.099

Sharma, P. (2010). Blended learning. ELT Journal, 64(4), 456-458. DOI:10.1093/elt/ccq043

Siegle, D. (2013). Technology: Differentiating Instruction by Flipping the Classroom. Gifted Child Today, 37(1), 51-55. doi:10.1177/1076217513497579

Snodin, N. S. (2013). The effects of blended learning with a CMS on the development of autonomous learning: A case study of different degrees of autonomy achieved by individual learners. Computers \& Education, 61, 209-216. DOI:10.1016/j.compedu.2012.10.004 